\title{
Karakteristik Gen Sitokrom C Oksidase Sub Unit I (CO1) Lebah Liar Apis cerena (Hymenoptera: apidae) Asal Pulau Hoga Sulawesi Tenggara
}

\author{
(CHARACTERISTICS OF GEN CYTOCHROME C OXIDASE SUBUNIT I(COI) \\ WILD BEES Apis cerena (Hymenoptera: Apidae) \\ FROM THE HOGA ISLAND OF SOUTH EAST SULAWESI)
}

\author{
Suriana $^{1^{*}}$, Jamili ${ }^{1}$, Parakkasi ${ }^{2}$ \\ ${ }^{1}$ Jurusan Biologi, Fakultas Matematika Ilmu Pengetahuan Alam, Universitas Halu Oleo, \\ ${ }^{2}$ Jurusan Pendidikan Biologi, Fakultas Keguruan Ilmu Pendidikan, UHO. \\ Kampus Hijau Bumi Tri Darma, Anduonohu, Kendari, Sulawesi Tenggara \\ Telp. (0401)391929, Fax. (0401)390496, \\ Email: suriana0568@gmail.com
}

\begin{abstract}
ABSTRAK
Penelitian ini bertujuan untuk menentukan karakteristik gen cytochrome oxidase subunit I (COI) dan mendeteksi situs barcode gen tesebut pada lebah liar Apis cerena. Total 15 ekor A. cerena ditangkap dari pulau Hoga, Sulawesi Tenggara. DNA genom diekstraksi dari toraks lebah, selanjutnya gen COI-nya diamplifikasi dengan metode PCR, kemudian disekuensing. Hasil sekuensing dikarakterisasi runutan nukleotida dan asam aminonya. Hasil penelitian adalah ujung ' 5 sekuen nukleotida COI lebah liar sepanjang 595 pasang basa. Sekuen tersebut bersifat kekal pada kebanyakan situs. Nukleotida didominasi oleh basa timin dan adenine $( \pm 70 \%)$. Terdapat 25 situs barcode untuk lebah liar dan 2 diantaranya unik bagi lebah liar asal pulau Hoga Sultra. Nukleotida sepanjang 595 tersebut, diprediksi mengkode 198 asam amino. Setelah disejajarkan dengan asam amino data genbank, asam amino tersebut menunjukkan variasi antar spesies sebesar 11\%. Asam amino ke 91 (treonin) dan asam amino ke 103 (asparagin) merupakan asam amino penciri/diagnostik bagi A.cerena asal pulau Hoga Sulawesi Tenggara. Filogeni molekuler yang direkonstruksi berdasarkan runutan nukleotida maupun asam amino, menunjukkan bahwa $A$. cerena dari Pulau Hoga berkerabat dekat dengan $A$. cerena sumber Genbank.
\end{abstract}

Kata-kata kunci: Lebah Liar, Apis cerena, situs barcode, asam amino diagnostic.

\begin{abstract}
The study was conducted to assess the caracteristic of cytochrome $\mathrm{C}$ oxidase subunit I (COI) gene on wild honey bee Apis cerena, and detection of barcode sites from these gene. A total fifteen individual $A$. cerena were collected from Hoga Island, Southeast Sulawesi. Genomic DNA was extracted from torax, then amplified by PCR method and than sequenced. Sequencing result characterized their nucleotide and amino acid content. The results showed that 595 nucleotides at the 5 ' end of COI gene of $A$. cerena very conserved at the most of the sites. Nucleotide dominated by thymine and adenine bases $( \pm 70 \%)$. There are 25 barcoding sites for $A$. cerena. There are two of these sites are diagnostics for $A$. cerena from of the Hoga Island. From of 595 basepairs nucleotide were prediction encode 198 amino acid, and only eleven percent of the these are varied between species. Amino acid $91^{\text {th }}$ (treonine) and $103^{\text {th }}$ (asparagin) were diagnostics amino acid for A. cerena from Hoga Island, Southeast Sulawesi. Molecular phylogeny reconstructed based on both nucleotide and amino acid sequence placing apis cerena from Hoga Island, Souteast Sulawesi is closely related to Apis cerena from Genbank source.
\end{abstract}

Key word: Wild honey bee, Apis cerena, barcode sites and diagnostics amino acid. 


\section{PENDAHULUAN}

Akhir-akhir ini, runutan DNA mitokondria (mtDNA) menjadi pilihan untuk mempelajari taksonomi, populasi dan evolusi hewan. Beberapa aspek struktur dan evolusi menyebabkan mtDNA menjadi pilihan, antara lain: memiliki banyak copy dalam sel sehingga memudahkan untuk memperoleh sampel yang diinginkan, tidak mengalami rekombinasi sehingga tidak dikacaukan oleh perubahan genetik akibat rekombinasi, memiliki daerah terkonservasi antar taksa sehingga dapat dijadikan sebagai template untuk desain primer yang bersifat universal, sekaligus daerah yang bervariasi laju evolusinya, sehingga dapat menunjukkan perbedaan antar taksa (Bernasconi et al., 2001: Caccone et al., 2004; Wells et al., 2001). Dibandingkan dengan gen kromosomal (gen inti), mtDNA memiliki laju evolusi 1-10x lebih cepat (Avisa 1987; Caccone et al., 2004; Lin \& Danforth 2004). Terdapat beberapa peta genome mitokondria (mtDNA) yang dapat dijadikan sebagai referensi atau perbandingan antar organisme (Liu et al., 2008; Kim et al., 2009; Liao et al., 2010; Friedrich \& Muqim 2003; Morlais \& Severson 2002). Ketepatan pilihan pada sekuen yang akan dijadikan sebagai marka genetik, merupakan hal yang mendasar dalam kajian evolusioner. Karakteristik penting yang harus diperhatikan sebagai marka genetik adalah laju substitusi nukleotida/asam amino pada daerah-daerah tertentu. Gen cytochrome $C$ oxidase sub unit I (COI) memiliki karakteristik khusus yang sesuai sebagai alat dalam kajian evolusioner, yaitu (1) sebagai pengkatialisis terakhir dalam rantai respirasi di mitokondria, sehingga COI banyak dikaji pada level biokimia, dan menunjukkan bahwa struktur dan ukuran gen COI terkonservasi pada semua organisme aerobik (Lunt et al., 1996). (2) Runutan asam amino berkorelasi dengan fungsi masing-masing bagian COI, sehingga menunjukkan karakteristik bagi spesies yang memilikinya (Lunt 1996; Roe \& Sperling 2007). (3) Dibandingkan dengan gen pengkode protein lain yang terdapat pada mtDNA, COI memiliki ukuran yang relatif besar, sehingga memudahkan untuk memilih daerah yang akan dipergunakan untuk kajian genetik, maupun fungsinya (4). Sekuen 658 basepair (bp) pada ujung 5' diusulkan sebagai barcode hewan (Heber et al., 2003 a, b). Barcode tersebut telah berhasil dibuktikan kemampuannya sebagai pembeda antar spesies pada Lepidoptera (Hebert et al., 2003a; Hajibabaei et al., 2005), gen ini juga telah dipergunakan untuk membuat barcode kupukupu Asterapes fulgerator (Hebert et. al., 2004), kumbang (Funk et al., 1995), beberapa serangga hama (Toda \& Murai 2007) ngengat Hamona mermerodes (Hulrc 2007), nyamuk (Cywinska et al., 2006). Sekuen COI dipergunakan untuk mengkaji koevolusi serangga herbivore dengan tanaman inangnya (Rivera et al., 2008)

Kajian mengenai lebah madu hasil domestikasi (Apis mellifera) telah dilakukan, baik aspek biologi,ekologi maupun aspek genetikanya (Arias, \& Sheppard, 1996; Arias, \& Sheppard, 2005; Ca'novas, et al., 2007; Corlett, 2011; Neekhra et al., 2012; Bharat et al., 2012). Kajian mengenai lebah madu liar juga telah dilakukan antara lain: Peng et al. (1989); Damus \& Otis (1997); Zhao et al. (2014); Rukhsana et al. (2014) dan lain-lain. Sejauh ini belum ada kajian mengenai aspek biologi, ekologi maupun genetic Apis cerena asal Sulawesi Tenggara, padahal data base suatu spesies sangat dibutuhkan demi pelestarian spesies tersebut.

Pada tulisan ini, dibahas mengenai karakteristik runutan nukleotida COI A. cerena, meliputi jumlah dan jenis substitusi yang ada dan menyebabkan keragaman antar spesies yang dibandingkan, komposisi nukleotida, potensi nukleotida dan asam amino penciri spesies dan menggunakan sekuen tersebut untuk merekonstruksi pohon kekerabatan antar spesies. Semua hasil penelitian dijelaskan berdasarkan latar belakang genetik yang menyertai, sehingga merupakan database molekuler pertama bagi Apis cerena asal Sulawesi Tenggara khususnya pulau Hoga.

\section{METODE PENELITIAN}

Penelitian ini merupakan penelitian eksploratif. Sampel lebah diperoleh dengan menangkap lebah di area sekitar tegakan magrove yang terdapat pada kawasan Taman Nasional wakatobi, yaitu pulau Hoga. Ekstraksi DNA dan amplifikasi gen sitokrom C oksidase sub unit I dilaksanakan di laboratorium Biologi Sub Forensif FMIPA UHO. Sedangkan sequencing gen dilaksanakan atas jasa perusahaan sekuensing DNA.

Prosedur ekstraksi DNA dilakukan sesuai dengan metode ektraksi pada penelitian sebelumnya (Suriana \& Nasaruddin, 2016), yang 
disederhanakan seperti berikut: Sampel dada lebah di gerus kemudian dicampurkan dengan buffer lysis yang mengandung CTAB, âmercaptoetanol, PVP. Setelah itu diinkubasi pada suhu $55^{\circ} \mathrm{C}$ selama 2 jam. Selanjutnya sampel disentrifugase pada kecepatan $6500 \mathrm{rpm}$ selama 3 menit. Supernatan diambil kemudian ditambah volume yang sama dengan isopropanol. Supernatan diambil dan dicampur dengan etanol dingin konsentrasi 100\% . Selanjutnya, sampel diinkubai pada suhu $-20^{\circ} \mathrm{C}$, selama 30 menit, kemudian dicentrifugase dengan kecepatan 13000 rpm selama 3 menit. Setelah itu, etanol di buang, pellet dicuci dengan etanol 70\%, kemudian dikering anginkan. Pellet diresuspensi dengan TE, dan diiukubasi pada suhu $37^{\circ} \mathrm{C}$, seama 15 menit.

Pengecekan hasil ekstraksi dilakukan dengan memigrasikan sampel melalui elektroforesis. Prosedur eletroforesis adalah: Gel agarose dibuat dengan buffer TBE, konsentrasi $1 \%$. Loading buffer berupa TBE $1 \mathrm{x}$, dengan volume disesuaikan untuk merendam gel agarose. Gel agarose dimasukkan ke dalam tangki elektroforesis yang telah diisi TBE 1X. Lima mikrolit sampel di loading dengan loading dye, kemudian dimasukkan ke dalam sumur agarose. Elektroforesis dihidupkan selama 30 menit. Setelah selesai, gel diviasualisasi dengan menggunakan gel ilumination. Sampel dengan band yang bagus/tegas selanjutnya di PCR untuk mengamplifikasi gen COI.

Untuk amplifikasi dipergunakan primer khusus untuk DNA barcode, yaitu: LepF1 'ATTCAACCAATCATAAAGATATTGG' sebagai priemer forward dan LepR1 TAAACTTCTGGATGTCCAAAAAATCA sebagai primer reversed (Hebert et. al., 2004). Campuran reaksi PCR terdiri atas buffer PCR (PCR kit ready to mix; KAPA HiFi Hot start, KAPABIOSYSTEM ) sebayak $12,5 \mu \mathrm{L}$, primer seperti yang tersebut sebelumnya, yaitu primer forward $10 \mu \mathrm{M}$ dan reversed $10 \mu \mathrm{M}$ masingmasing $0,75 \mu \mathrm{L}$, DNA template $1 \mu \mathrm{L}$, dan $10 \mu \mathrm{L}$ ddH2O (rekomendasi KAPPABIOSYSTEM). Mesin PCR, TC-PLUS Techne LTC 1038 disetting sesuai rekomendasi KAPPABIOSYSTEM produsen PCR kit, dengan denaturasi awal 3 menit pada suhu $95^{\circ} \mathrm{C}$, ikuti 35 siklus dari: denaturasi $15^{\prime \prime}$, pada $95^{\circ} \mathrm{C}$. Anneling $15^{\prime \prime}$, pada $55^{\circ} \mathrm{C}$. Ekstensi 30", pada $72^{\circ} \mathrm{C}$. Diiukuti post ekstensi pada 5', pada $72^{\circ} \mathrm{C}$. Hasil amplifikasi divisualisasikan dengan menggunakan elektroforesis. Band yang bersih dan tegas, di kirim ke perusahaan jasa sekuensing, yaitu PT. Genetika Science Indonesia untuk proses selanjutnya.

Hasil sekuensing diblast (akses langsung dengan: http://blast.ncbi.nlm.nih.gov. untuk meyakinkan bahwa hasil sekuensi adalah DNA target, yaitu gen COI. Setelah itu sekuen dikarakterisasi nukleotida dan asam aminonya. Sekuen COI pembanding yang tersedia pada Genbank, yaitu:

1. Apis mellifera mitochondrion, partial genome (KT 164631.1).

2. Apis mellifera mitochondrion, partial genome (KT164619.1).

3. Apis cerana isolate CL24 mitochondrion, partial genome (KM244704.1).

4. Apis cerana mitochondrion, complete genome (NC_014295.1).

5. Apis cerana haplotype 1 cytochrome oxidase subunit 1 (COI) gene, partial cds; (AF153101.1).

6. Apis cerana isolate 1 cytochrome oxidase subunit I (COI) gene, partial cds (KJ755566.1).

Sebagai out group dipakai sekuen COI Polistes sp. BOLD:ACO0792.

Analisis data dilakukan menggunakan software Bioedit dan MEGA versi 7. Sekuen pembanding (out group), diperoleh dari data GenBank. (http://nucleotida.ncbi.nlm.nih.gov.). Data disajikan dalam bentuk tabel dan gambar.

\section{HASIL DAN PEMBAHASAN}

Perunutan sekuen DNA hasil amplifikasi dengan metode PCR gen CO1 DNA mitokondria Apis cerena dari populasi asal pulau Hoga Sulawesi Tenggara menghasilkan DNA sepanjang 595-602 nukleotida (nt) (Gambar 1).

Nukleotida tersebut sejajar dengan posisi nukleotida ke 138 - 740 pada sekuen gen CO1 lebah pembanding dari data GenBank. Data sekuen yang dikarakterisasi sepanjang 595 nukleotida (Gambar 1), menyandi 198 asam amino.

Hasil pensejajaran $595 \mathrm{nt}$ (nukleotida) gen COI antar populasi $A$. cerena menunjukkan bahwa gen tersebut sangat conserved (bersifat kekal; dipertahankan) pada level spesies, tetapi menunjukkan keragaman dibandingkan dengan spesies lain, baik dari famili yang sama (Apidae), maupun dengan famili yang berbeda (Polistidae). Terdapat 75\% (444/595) nukleotida yang bersifat conserved, dan 25\% (151/595) nukleotida variabel. Nukleotida variabel, terdiri atas $18 \%$ (108/595) nukleotida parsimony informative dan 


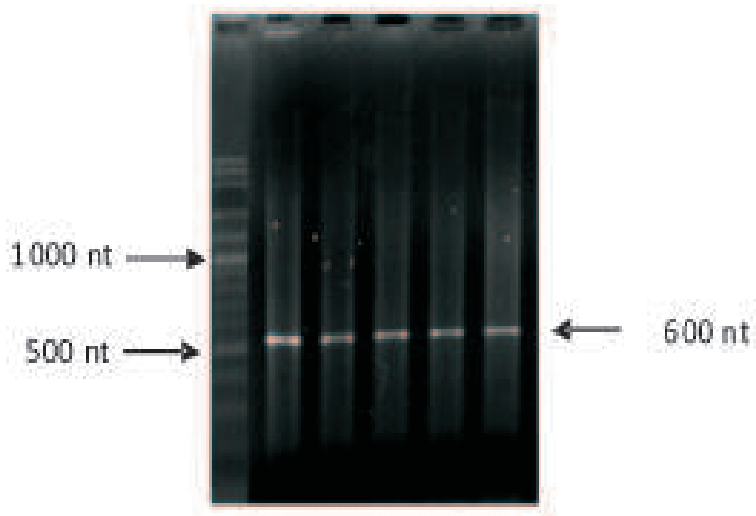

Gambar 1. Profil DNA COI A. cerena hasil amplifikasi dengan primer RCO1 dan FCOI. Marker 100 nt (1), contoh sampel yang teramplifikasi $(2 \mathrm{~s} / \mathrm{d} 6)$.

7\% (43/595) nukleotida singleton. Nukleotida parsimoni informatif terdiri atas $80.6 \%$ (87/108) terdapat pada kodon ketiga, dan sisanya yaitu 19.4\% (21/108) terdapat pada kodon pertama.

Komposisi masing-masing basa $\mathrm{N}$ antar spesies yang dibandingkan terdiri atas 38\% $40.7 \%$ timin (T), $27.6 \%-30.6 \%$ adenin (A), $15.8 \%$ - $18.5 \%$ sitosin (C), dan $13.3 \%-14.6 \%$ guanin (G). Dominasi basa T dan A pada masing-masing spesies terutama terdapat pada kodon ke tiga. Komposisi nuleotida pada COI A. cerena relatif konsisten dengan komposisi nukleotida yang ditemukan pada sekuen COI serangga lainnya, khususnya Hymenoptera. Kecenderungan dominasi basa timin dan adenin disebabkan oleh penggunaan basa tersebut sebagai kodon triplet. Penggunaaan kodon triplet berhubungan dengan ketersediaan tRNA yang bersesuaian dan juga laju ekpresi gen. Selain itu komposisi nukleotida berhubungan dengan laju substitusi. Sustitusi transisilebihnbesar dibanding dengan substitusi transversi. Hal tersebut sejalan dengan hasil penelitian ini, dan seperti yang ditemukan oleh Toda \& Murai (2008), substitusi A"!G, lebih besar dari pada C"!T, mutasi sinonim > mutasi non sinonim. Oleh karena adanya subtitusi maka ditemukan 25 situs diagnostik pada nukleotida COI yang dapat diperukan sebagai penciri bagi A.cerena.

Terdapat 25 situs nukleotida COI A. cerena yang berbeda dengan spesies lain dan bersifat diagnostic, sehingga beberapa diantaranya dapat dipergunakan sebagai penciri bagi spesies tersebut. Jumlah nukleotida berbeda disajikan pada Tabel 1.

Tabel 1. Matriks perbedaan nukleotida COI (595 nt) antara A. cerena dengan COI dari data GenBank

\begin{tabular}{llllllll}
\hline & 1 & 2 & 3 & 4 & 5 & 6 & 7 \\
\hline$[1]$ & & & & & & & \\
{$[2]$} & 74 & & & & & & \\
{$[3]$} & 79 & 39 & & & & & \\
{$[4]$} & 73 & 47 & 56 & & & & \\
{$[5]$} & 82 & 55 & 46 & 55 & & & \\
{$[6]$} & 72 & 55 & 38 & 46 & 54 & & \\
{$[7]$} & 69 & 15 & 37 & 44 & 53 & 14 & \\
\hline
\end{tabular}

1: A. cerena (Sultra), 2 s/d 4:A.cerena (GenBank), 5 dan 6: A. mellifera (Genbank), 7.Polistes sp

Tabel 2. Situs diagnosti antar spesies berdasarkan 595 nukleotida gen COI

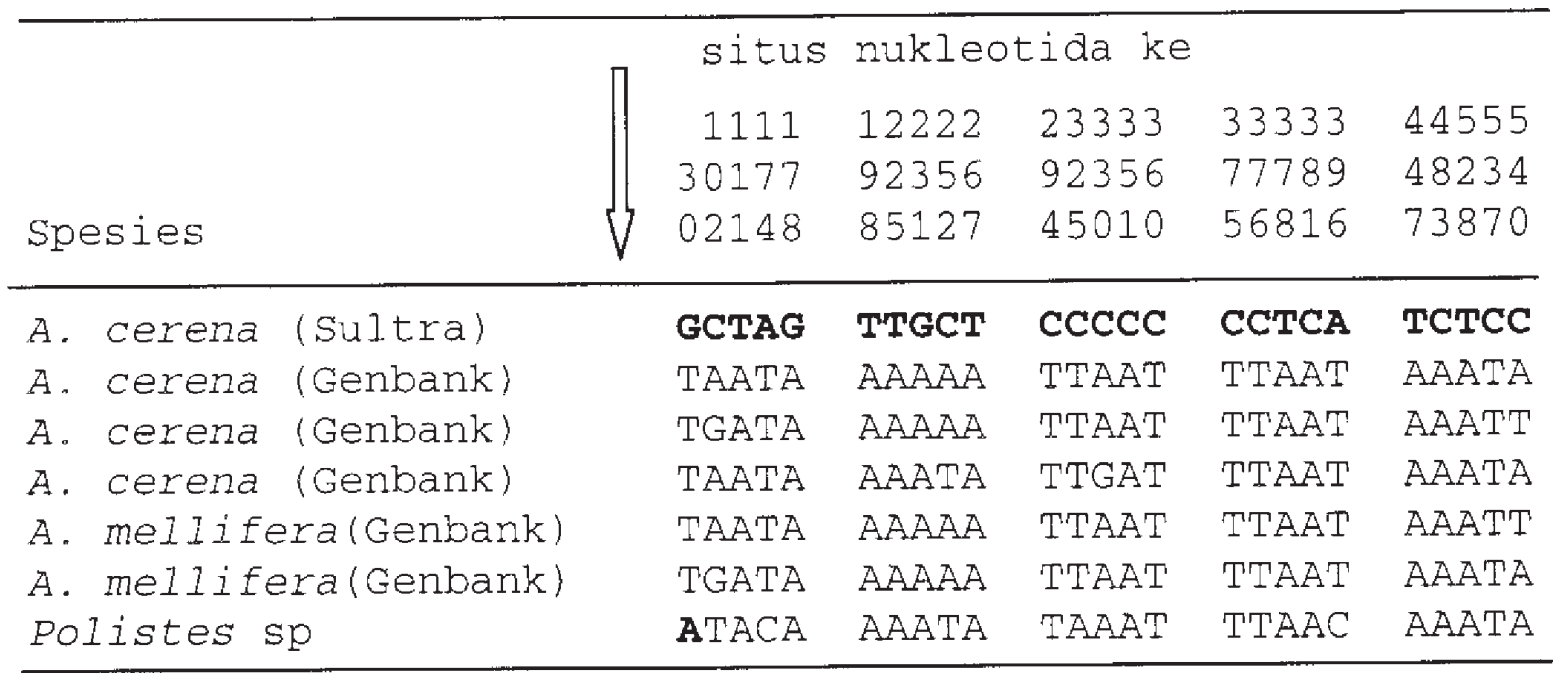

Ket: G: guanine, A: adenin, C: sitosin, T: timin. 
Dengan kisaran perbedaan nukleotida antar spesies yaitu 14-84, terdapat 25 situs diagnostik untuk spesies A. cerena (Tabel 2).

Terdapat perbedaan kecil jarak genetik antar spesies yang dibandingkan berdasarkan metode Neighbor-Joining, model $p$-distance dan Kimura 2-parameter. Meskipun demikian, ada konsistensi dalam hal besarnya jarak yang dihasilkan (Tabel 3).

Berdasarkan jarak genetik pada Tabel 3, maka topologi filogeni antar spesies baik menggunakan model $p$-distance maupun menggunakan model Kimura 2-parameter, adalah sama (konsisten) sehingga hanya satu filogeni yang ditampilkan (Gambar 2).

Pada Gambar 2, nampak bahwa A.cerena berada pada satu nodus dengan $A$. cerena (GenBank) dengan nilai boostrap 95\%. Di luar nodus ini, terdapat nodus yang ditempati oleh kelompok Apidae lainnya, yaitu A. mellifera dari data Genbank dengan nilai boostrap 100\%. Pada nodus terluar, terdapat Polistes sp. sebagai

Tabel 3. Jarak genetik antara A. cerena dengan spesies dari data Genbank, berdasarkan runutan 595 nukleotida COI dengan model $p$-distance di bawah diagonal dan Kimura 2-parameter di atas diagonal

\begin{tabular}{llllllll}
\hline & 1 & 2 & 3 & 4 & 5 & 6 & 7 \\
\hline$[1]$ & - & 0.14 & 0.15 & 0.13 & 0.15 & 0.13 & 0.13 \\
{$[2]$} & 0.12 & - & 0.07 & 0.08 & 0.10 & 0.01 & 0.03 \\
{$[3]$} & 0.13 & 0.07 & - & 0.10 & 0.08 & 0.07 & 0.07 \\
{$[4]$} & 0.12 & 0.08 & 0.09 & - & 0.10 & 0.08 & 0.08 \\
{$[5]$} & 0.14 & 0.09 & 0.08 & 0.09 & - & 0.10 & 0.10 \\
{$[6]$} & 0.12 & 0.01 & 0.06 & 0.08 & 0.09 & - & 0.02 \\
{$[7]$} & 0.12 & 0.03 & 0.06 & 0.07 & 0.09 & 0.02 & - \\
\hline
\end{tabular}

1: A. cerena (Sultra), 2 s/d 4:A.cerena (GenBank), 5 dan 6: A. mellifera (Genbank), 7.Polistes $\mathrm{s}$

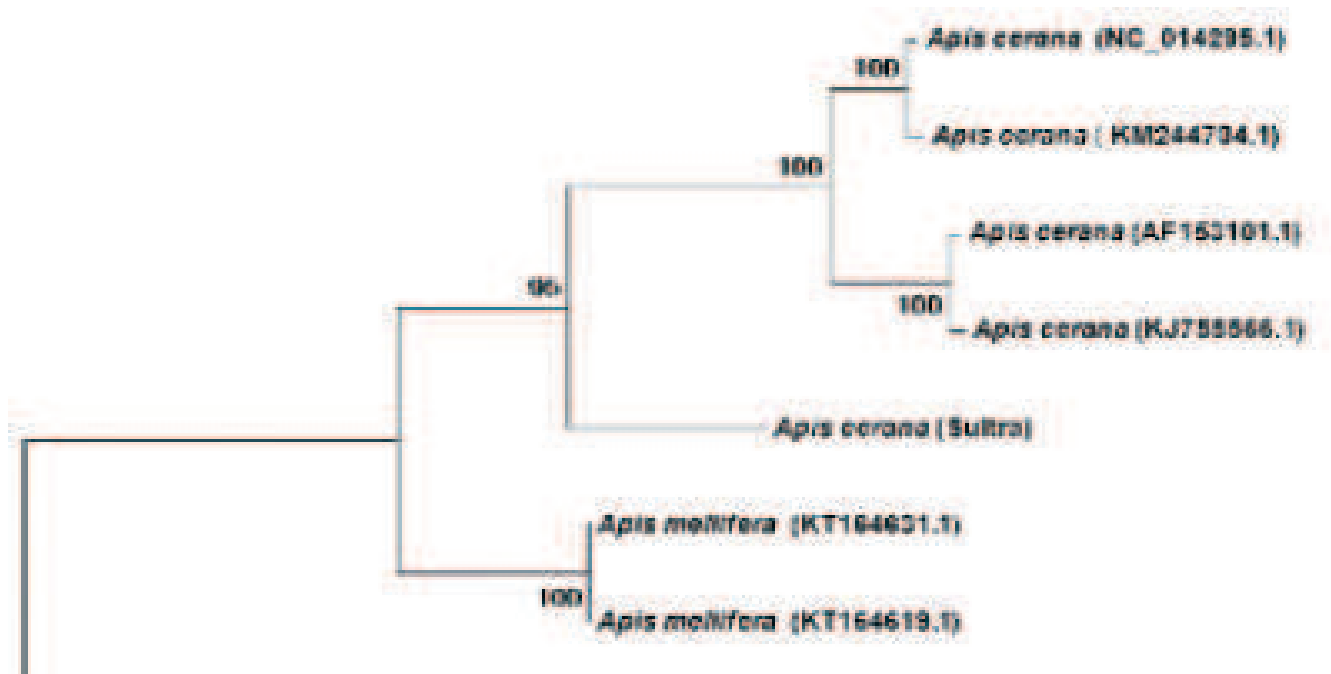

POAStes sp. |EOLO:ACO07a2

\section{e ased}

Gambar 2. Filogeni berdasarkan runutan 595 nukleotida COI dengan metode Neighbor-Joining, bootstrapped 1000x, model Kimura 2-Parameter. 
outgroup. Hal ini berarti bahwa diantara sesama Apidae, maka A.cerena memiliki hubungan kekerabatan terdekat dengan $A$.cerena dari data Genbak. Didukung oleh nilai boostrap $>50 \%$, maka filogeni tersebut bersifat robust. Filogeni tersebut juga nyata menunjukkan bahwa Apis menunjukkan filogeni yang bersifat monofiletik (satu nenek moyang, yang kemudian berkembang menjadi berbeda; $A$. cerena dan $A$. mellifera).

Penelitian ini berhasil mengkarakterisasi runutan nukleotida pada ujung 5' gen COI $A$. cerena sepanjang 595 nukleotida (nt). Nukleotida didominasi oleh basa adenine dan timin, dan bersifat conserve pada $A$. cerena. Meskipun demikian, dibandingkan dengan spesies lain, dari sesama famili Apidae dan famili lain (Polistidae) nukleotida tersebut cukup beragam. Hal ini sejalan banyak penelitian yang dilakukan pada serangga, baik pada level genus, famili maupun ordo. Keragaman nukleotida intra spesies berdasarkan gen COI rendah (<1\%) juga ditemukan oleh Li et al.(2009); Wagener et al. (2006); Cywinska et al. (2006). Meskipun demikian, pada level genus, COI berhasil memisahkan kumbang genus Ophraella dengan sekuen DNA COI sepanjang 446 nt dan menunjukkan keragaman antar spesies sebesar 24\% (Funk et al., 1995), kumbang genus Mesechthistatus (Nakamine \& Takeda 2007), serangga hama tembakau Thrips tabaci sebesar 4,8\% (Toda \& Murai 2007), dan nyamuk (Culicidae) 0.2-17.2\% Cywinska et al. (2006). Pada level famili Mahendran et al. (2006), menyatakan bahwa COI menghasilkan topologi filogeni yang robust dibandingkan sekuen rRNA. COI memisahkan dengan tegas famili Saturniidae dengan famili Bombycidae. Pada nyamuk, COI memisahkan 3 sub famili yaitu Anophelinae, Culicinae and Toxorhynchitinae sebesar 17.2 - 26.3\% (Cywinska et al., 2006). Bahkan COI dipergunakan untuk memisahkan hewan pada level yang lebih tinggi antara lain Lepidoptera (Hajibabaei et al., 2007).

Rendahnya keragaman pada COI intra populasi A.cerena disebabkan oleh karena mekanisme reproduksi, sinkronisasi waktu kawin, pola sebaran dan pemilihan relung. Induk betina meletakkan telur hanya sekali pada tempat yang sama, dengan demikian peluang bagi generasinya untuk bercampur dengan generasi dari kelompok telur yang lainnya kecil, sehingga tidak ada aliran genetik. Populasi yang berkembang ketika itu hanyalah turunan dari pasangan imago yang berada pada habitatrelung tersebut. Demikian juga sinkronisasi waktu kawin, pada $A$. cerena tidak selalu bersamaan, sehingga mengurangi kesempatan perkawinan antar imago dari populasi lainnya. Hal demikian juga ditemukan pada populasi mayfly Baetis bicaudatus (Ephemeroptera: Baetidae), from the Rocky Mountains, Colorado (Hughes et al., 2003).

Nukleotida COI sepanjang 595 nt, ditranslasi menjadi 198 asam amino. Asam amino tersebut sejajar dengan posisi ke 47 dari asam amino $A$. cerena (complete mitochondria, data Genbank) sebagai acuan. Asam amino COI A. cerena, terkonservasi pada level spesies. Komposisi asam amino didominasi oleh leusin dan isoleusin (> 25\%), sedangkan asam amino lainnya terdapat dalam jumlah yang lebih kecil.

Berbeda halnya dengan nukleotida, hasil pensejajaran asam amino COI $A$. cerena dengan asam amino data GenBank, menunjukkan keragaman yang kecil, yaitu hanya $1 \%$. Terdapat 176/198 (88.8\%) asam amino yang conserved, sisanya yaitu 22/198 (11.1\%) asam amino variabel. Situs asam amino berbeda pada spesies yang dibandingkan, disajikan pada Tabel 3, dan jumlah perbedaan asam amino serta jarak genetik antar spesies disajikan pada Tabel 4.

Berdasarkan Tabel 4, maka asam amino yang unik (khas) pada masing-masing spesies adalah: F (asam amino ke 53) dan P (asam amino ke 179) untuk A.cerena (NC 014295.1), A (asam amino ke 144), unik bagi A.cerena (AF153101.1.), T (asam amino ke 144), unik bagi A.cerena (KJ755566.1), S (asam amino ke 70), unik bagi 2 haplotip $A$. mellifera, tetap berbeda pada asam amino ke 157, N (asam amino ke 127), unik bagi A.cerena (KM244704.1), T(asam amino ke 91) dan $\mathrm{N}$ (asam amino ke 103), unik bagi A.cerena asal Sultra. Data tersebut menunjukkan bahwa meskipun banyak nukleotida telah mengalami perubahan, tetapi pada dasarnya asam amino bagi speseis hampir hanya berbeda sedikit. Hal ini disebabkan oleh karena adanya sifat degeneratif kode genetik, yaitu beberapa asam amino dapat dikodekan oleh lebih dari satu kodon, sehingga perubahan basa $\mathrm{N}$ ke 3 tidak adakan merubah asam amino yang dikodekan. Fenomena lebih sering disebut sebagai mutasi tidak berarti.

Berdasarkan jarak genetik tersebut pada Tabel 5, filogeni antar spesies berdasarkan runutan asam amino disajikan pada Gambar 3. 
Tabel 4. Situs asam amino berbeda pada gen COI A. cerena dan asam amino data GenBank

\begin{tabular}{|c|c|c|c|c|c|c|}
\hline \multirow{4}{*}{ Spesies } & \multicolumn{3}{|c|}{ Situs asam } & \multicolumn{3}{|l|}{ amino } \\
\hline & & & & 1111 & 11111 & 111 \\
\hline & 55 & 6667 & 8999 & 0012 & 24455 & 667 \\
\hline & 13 & 0180 & 8145 & 3421 & 70427 & 469 \\
\hline A.cerena (NC_014295.1) & IF & LFLY & YSND & MSSM & LFIVI & RFP \\
\hline A.cerena (AF153101.1.) &. $\mathrm{G}$ & $\ldots$ & . v. & $\ldots \mathbf{N}$ &.$A A$. & $\ldots \mathrm{N}$ \\
\hline A.cerena (KJ755566.1) & . & $\cdots$ & $\ldots \mathrm{VN}$ & $\ldots \mathbf{N}$ & . TA. & Q. \\
\hline A. mellifera (KT164631.1) & $\mathrm{v}$. & TLGS & A.V. & D.A. & M.G.N & $\cdots$ \\
\hline A.mellifera (KT164619.1 & $\mathrm{v}$. & TLGS & A.V. & D.A. & M.G.. &. $\mathrm{L}$. \\
\hline A.cerena (KM244704.1) & . & ... & $\cdots$ & $\ldots$ & $\mathbf{N} \ldots$ & . L . \\
\hline A.cerena (Sultra) & . & $\ldots$ &. $\mathbf{T}$. & N... & $\ldots .$. & ... \\
\hline Polistes sp. (DQ 172911.1) & M. & . MLD & G.V. & IAAN & H. LL . . & . L . \\
\hline
\end{tabular}

F: Fenilalanin, P: prolin, V:valin, T:treonin, G:glisin, S:serin, N:asparagin, Q:glutamine, A: alanin, M:metionin, L:leusin, D:asamaspartat, Y:tirosin, I: isoleusin. Huruf yang dicetak tebal: asam amino khas/ diagnostik.

Tabel 5 Jumlah asam amino COI berbeda antar spesies (di bawah diagonal) dan jarak genetik berdasarkan model $p$-distance (di atas diagonal)

\begin{tabular}{|c|c|c|c|c|c|c|c|}
\hline & 1 & 2 & 3 & 4 & 5 & 6 & 7 \\
\hline 1. Apis cerena (NC_014295.1) & & 0.01 & 0.01 & 0.02 & 0.02 & 0.01 & 0.01 \\
\hline 2. Apis cerena (AF153101.1.) & 0.03 & & 0.02 & 0.02 & 0.02 & 0.02 & 0.02 \\
\hline 3. Apis cerena (KJ755566, 1) & 0.04 & 0.04 & & 0.02 & 0.02 & 0.02 & 0.02 \\
\hline 4. Apis mellifera (KT 164631.1) & 0.07 & 0.09 & 0.08 & & 0.01 & 0.02 & 0.02 \\
\hline 5. Apis mellifera (KT 164619.2) & 0.07 & 0.09 & 0.09 & 0.02 & & 0.02 & 0.02 \\
\hline 6. Apis cerena (KM244704.1) & 0.02 & 0.05 & 0.05 & 0.08 & 0.06 & & 0.02 \\
\hline 7. Apis cerena (Sultra) & 0.02 & 0.04 & 0.04 & 0.07 & 0.07 & 0.04 & \\
\hline
\end{tabular}

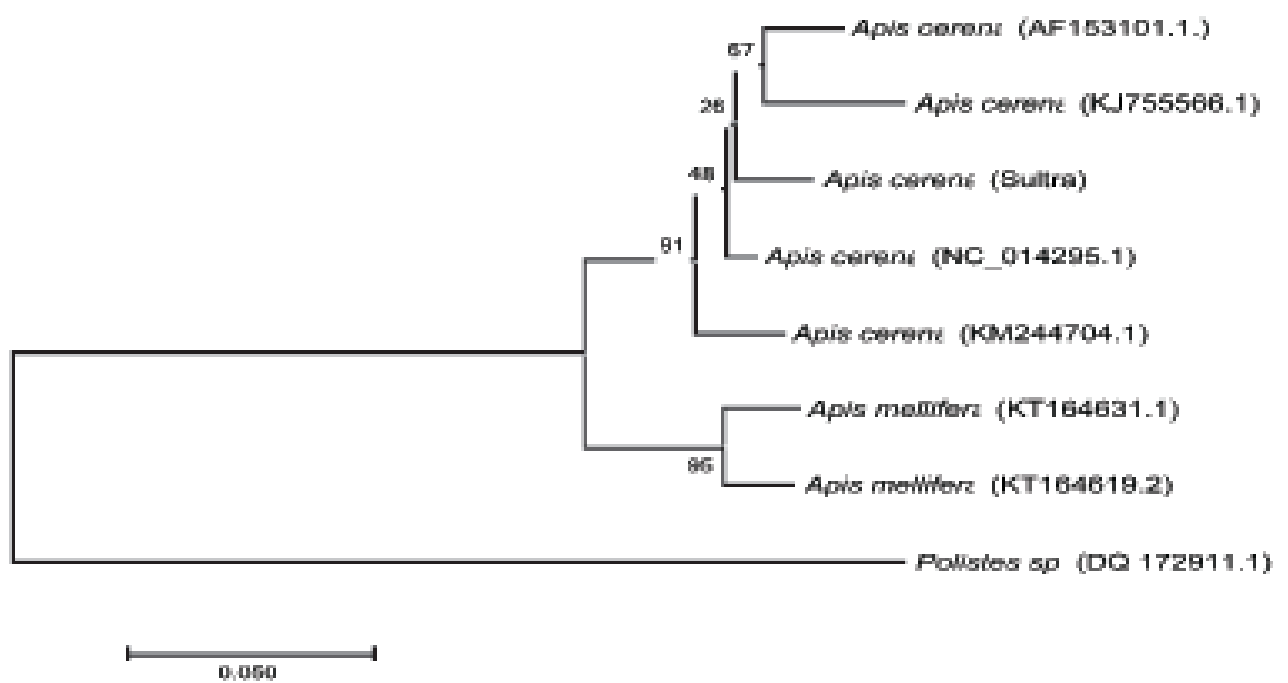

Gambar 3. Filogeni berdasarkan runutan 198 runutan asam amino COI dengan metode NeighborJoining, bootstrapped 1000x, model p-distance. 
Keberadaan asam amino COI pada mitokondria berhubungan erat dengan 2 fungsi, yaitu sebagai bagian struktural membran dalam mitokondria (protein trans membrane), dan akseptor (penerima) elektron terakhir dalam rantai respirasi sel. Sebagai bagian struktural, COI berupa polipeptida yang berlipat beberapa kali menembus dwilapis lipid membran. Lunt et al. (1998) telah mengekplorasi gen COI dalam hubungannya dengan pola evolusi dan primer konserve untuk kajian filogeni. Ternyata berdasarkan strukturnya, laju evolusi pada setiap bagian dari asam amino bervariasi. Hal ini berhubungan dengan fungsi bagian-bagian tersebut. Olehnya itu, maka penggunaan segmen DNA COI untuk tujuan yang sama, sangat bergantung pada fragmen yang dipergunakan. Untuk barcoding hewan, (Hebert et al. 2003a,b) mengusulkan penggunaan 648 bp pada ujung 5' sekuen COI.

Penelitian ini menunjukkan bahwa filogeni berdasarkan runutan nukleotida maupun asam amino COI menempatkan Apidae sebagai family monophyletic. Berbeda halnya jika filogeni dibangun berdasarkan runutan nukleotida (Gambar 2); pada Gambar 3, dimana filogeni disusun berdasarkan runutan asam amino, menempatkan $A$. cerena tetap dekat dengan $A$. cerana lainnya, setelah nodus terdalam yang ditempati oleh $A$. cerena AF 153110.1 dan KJ755566.1, dan pada nodus di luarnya ditempati oleh A.cerena NC 014296.1. Setelah itu, nodus bagi $A$. mellifera. Hal ini disebabkan oleh karena meskipun nukleotida cukup beragam antar spesies Apidae, tetapi tidak demikian dengan asam aminonya (Tabel 3 dan 4). Penggunaan outgroup yang berbeda jauh ketika membangun filogeni terkadang menimbulkan perbedaan topologi pohon kekerabatan (Funk et al., 1995), tetapi hal tersebut tidak terjadi pada A. cerena.

Data molekuler dapat dipergunakan untuk melengkapi data morfologi, anatomi maupun perilaku dalam kajian taksonomi hewan. Data yang diperoleh pada penelitian ini merupakan data awal bagi Apis cerena khususnya yang berasal dari Sulawesi Tenggara. Oleh karena itu diharapkan data ini dapat bermanfaat sebagai sumber informasi yang berguna untuk penelitian serupa di masa datang.

\section{SIMPULAN}

Penelitian ini berhasil mengkarakterisasi 595 nukleotida pada ujung 5' gen COI Apis cerena. Dari nukleotida tersebut ditemukan 25 situs diagnostik yang merupakan penciri bagi spesies A. cerena. Nukleotida yang diperoleh menyandi 198 asam amino. Dari jumlah tersebut, diperoleh dua asam amino penciri bagi spesies A. cerena, yaitu asam amino ke 91 (treonin) dan asam amino ke 103(Asparagin). Berdasarkan runutan nukleotida dan asam amino, filogeni menunjukkan bahwa famili Apidae bersifat monophyletic.

\section{DAFTAR PUSTAKA}

Arias, M. C., and W. S. Sheppard. 1996. Molecular phylogenetics of honey bee subspecies (Apis mellifera L.) inferred from mitochondrial DNA sequence. Mol. Phylogenet. Evol. 5:557-566.

Arias, M. C., and W. S. Sheppard. 2005. Phylogenetic relationships of honey bees (Hymenoptera:Apinae:Apini) inferred from nuclear and mitochondrial DNA sequence data. Mol Phylogenet Evol 37:25-35.

Avisa 1998. The history and purview of phylogeorgaphy: a personal reflection. $\mathrm{Mol}$ Ecol 7: 371- 379.

Bernasconi MV, Pawlowski J, Valsangiacomo C, Piffaretti JC, Ward PI. 2001. Phylogeny of the genus Scathophaga (Diptera: Scathophagidae) inferred from mitochondrial DNA sequences. Can J Zool 79: 517-524.

Bharat N, Pandy D, Mishra m, Jain SK. 2012. Molecular Approach in Honey bee: A Review. Int J Pharm Bio Sci 3(3): 261 - 271.

Cacccone, A, Gentile, G, Burn CE, Sezzi, E, Bergman, W, Ruelle, M, Saltonstall, K., and Powell, Jr. 2004. Extreme difference in rate of mitochondrial and nuclear DNA evolution in a large ectotherm, Galapagos tortoises. Mol Phylogenet Evol 31:794-798.

Ca'novas, F, Ru PD, Serrano J, and Galia 'n J. 2007. Geographical patterns of mitochondrial DNA variation in Apis mellifera iberiensis (Hymenoptera: Apidae). J Zool Syst Evol Res 46:24-30. 
Corlett, R. T. 2011. Honeybees in natural ecosystems. in H. R. Hepburn and S. E. Radloff, eds. Honeybees of Asia. SpringerVerlag, Berlin. Pp. 215-225.

Cywinska AC, Hunter FF, Hebert PDN. 2006. Identifying Canadian mosquito species through DNA barcodes Medical and Vet Entomology 20: 413-424.

Damus MS, Otis GW. 1997. A morphological analysis of A.cerana F. and A. nigrocincta Smith populations from Southeast Asia. Apidologie 28:309-319.

Fredict M, Muqim N. 2003. Sequence and phylogenetic analysis of the complete mitochondrial genome of the flour beetle Tribolium castanaeum. Mol Phylogenet and Evol 56: 502-512.

Funk DJ, Futuyma DJ, Orti G, Meyer A. 1995. Mitochondrial DNA sequence and multiple data sets: A phylogenetic study of phyotophagus beetles (Chrysomelidae: Ophraella). Mol Biol Evol 12: 627-640.

Hajibabaei M, Janzen DH, Burns JM, Hallwachs W, Hebert PDN. 2005. DNA Barcodes Distinguish Species of Tropical Lepidoptera. PNAS 103:968-971.

Hajibabaei M G, Singer AC, Clare EL and Hebert PDN. 2007. Design and Applicability of DNA Arrays and DNA Barcodes in Biodiversity Bionitoring BMC Biology 5:24.

Hebert PDN, Cywinska A, Ball SL, and deWaard JR. 2003a. Biological identifications through DNA barcodes Proc $R$ Soc Lond B 270:31321.

Hebert PDN, Ratnashingham S, deWaard JR. 2003b. Barcoding animal life: cytochrome $\mathrm{C}$ oxidase subunit I divergences among closely related species. Proc $R$ Soc Lond B 02PB0653:1-9.

Hebert PDN, Penton EH, Burns JM, Jansen DH, and Hallwachs. 2004. Ten species in one: DNA barcoding reveals cryptic species in the neotropical skipper butterfly Astraptes fulgerator.PNAS 101(41): 14812-14817

Hughes JM, Mather PB, Hillyer JM, Cleary C, Peckarsky B. 2003. Genetic structure in a montane mayfly Baetis bicaudatus (Ephemeroptera: Baetidae), from the Rocky Mountains, Colorado Freshwater Biology 48: 2149-2162.
Hulcr J, Miller SC, Darrow GPSK, Muller DN, Hebert PDN, Weiblen GD. 2007. DNA barcoding confirms polyphagy in a generalist moth, Hontona mermerodes (Lepidoptera: Tortricidae). Mol Ecol Notes 7:549-557.

Kim SR, Kim ML, Hong MY, Kim KY, Kang PD, Hwang JS, Han YS, Jin BY, Kim I. 2009. The complette mitogene sequence of the Japanese oak silkmoth, Antheraea yamamai (Lepidoptera: Saturnidae). Molecular Biology Reproduction 36: 19711880.

Liao F, Wang L, Wu S, Li YP, Zhao L, Huang GM, Niu CJ, Liu YQ, Li MG. 2010. The complete mitochondrial genome of the fall webworm, Hypanthria cunea (Lepidopter: Articdae). Int. J. of Biol. Science 6: 172-186.

Li AL, Zhao Q. Shunmingtang. Hang Z. 2009. Molecular phylogeny of the domesticated silkworm, Bombyx mori, based on the sequences of mitochondrial cytochrome $b$ genes. J Genet 84:137-142.

Lin CP, Danforth BN 2004. How do insect nuclear and mitochondrial gene substitution patterns differ? Insights from Bayesian analyses of combined datasets. Molecular Phylogenetics and Evolution 30: 686-702.

Liu1 Y, L Y, Pan M, Dai F, Zhu X, Lu C, and Xiang Z. 2008. The complete mitochondrial genome of the Chinese oak silkmoth, Antheraea pernyi (Lepidoptera: Saturniidae). Acta Biochim Biophys 40:693703.

Lunt DH. Zhang DS, Zhimura DM, Dewit GM. 1996. The insect cytochrome oxidase I gene: evolutionary pattern and conserve primer for phylogenetics studies.Insect Molecular Biology 5: 153-163.

Mahendran B, Padhi BK, Sudip K, Ghosh, Kundu, SC.2006. Genetic Variation in Ecoraces of Tropical Tasar Silkworm, Antheraea mylitta Using RFLF Technique. Current Science 90:100-103.

Morlais I, Severson DW. 2002. Complete Mitochondrial DNA Sequence and Amino Acid Analysis of the Cytochrome C Oxidase Subunit I (COI) from Aedes aegypti. DNA Sequence 13: 123-127.

Nakamine H, Takeda M. 2007. Molecular phylogenetic relationships of flightless beetles belonging to the genus 
Mesechthistatus Breuning, (Coleoptera: Cerambycidae) inferred from mitochondrial COI gene sequences. J. of Insect Science 8:70-81.

Neekhra B, Pandey D, Mishra M, Jain SK. 2012. Molecular marker approach in honey bee: A Review. International Journala of Pharma and Bio Science 3:261-271.

Peng YS, Nasr ME, Loske SJ. Geographical races of A.cerana Fabricius in China and their distribution. Review of recent Chinese publications and a preliminary statistical analysis. Apidologie 1989; 20:9-12.

Rivera JAJ, Vogler AP, Reid CAM, Petitpierre M, Zurita J. 2009. DNA barcoding insecthost plant associations. Proc $R$ Soc $B$ 276: 639-648.

Roe AD, Sperling FAH 2007. Patterns of evolution of mitochondrial cytochrome $\mathrm{C}$ oxidase I and II DNA and implications for DNA barcoding Molecular Phylogenetics and Evolution 44: 325-345.

Rukhsana K, Akhilesh VP, and Sebastian CD. 2014.Deciphering the molecular phylogenetics of the Asian honey bee, Apis cerana and inferring the phylogeographical relationships using DNA barcoding. Journal of Entomology and Zoology Studies 2014; 2 (4): 218-220.

Suriana, Nasaruddin. 2016. Karakteristik Partial Gen Sitokrom-C Oksidase Subunit I Katak Pohon Suaka Marga Satwa Tanjung Peropa, Moramo Sulawesi tenggara.Jurnal Veteriner 17 (4):517-523.

Toda S, Murai T. 2007. Phylogenetic analysis based on mitochondrial COI gene sequences in Thripstabaci Lindeman (Thysanoptera: Thripidae) in relation to reproductive forms and geographic distribution Appl. Entomol. Zool. 42: 309-316.

Weagner B, Reineke A, Lohr B, Zebit PW.2006. Phylogenetic study of Diadegma species (Hymenoptera: Ichneumonidae) inferred from analysis of mitochondrial and nuclear DNA sequence. Biological Control 37: 131140.

Zhao W, Tan K, Zhou D, Wang M, Cheng C, Yu Z. and Miao. 2014. Phylogeographic analysis of Apis cerana populations on Hainan Island and southern mainland China, based on mitochondrial DNA sequences. Apidologie 45:21-33. 